\title{
Long-term climate record inferred from early-middle Pleistocene amphibian and squamate reptile assemblages at the Gran Dolina Cave, Atapuerca, Spain
}

\author{
Hugues-Alexandre Blain ${ }^{\mathrm{a}, *}$, Salvador Bailon ${ }^{\mathrm{b}}$, Gloria Cuenca-Bescós ${ }^{\mathrm{c}}$, Juan Luis Arsuaga ${ }^{\mathrm{d}, \mathrm{e}}$, \\ José Maria Bermúdez de Castro ${ }^{\text {f }}$, Eudald Carbonell ${ }^{\mathrm{a}}$ \\ ${ }^{a}$ Institut de Paleoecologia Humana i Evolució Sociai, Àrea de Prehistöria, Universitat Rovira $i$ Virgill, Plaça Imperial Tarraco 1, E-43005 Tarragona, Spain \\ ${ }^{\mathrm{b}}$ Laboratoire départemental de Préhistoire du Lazaret, 33bis Boulevard Franck Pilatte, F-06300 Nice, France \\ 'Áre de Paleontología, Dpto. Ciencias de la Tierra, Facultad de Ciencias, Universidad de Zaragoza, E-50009 Zaragoza, Spain \\ ${ }^{d}$ Centro de Investigación (UCM-ISCIII) sobre la Evolución, y Comportamiento Humanos, c/Sinesio Delgado, 4 (Pabellón 14), E-28029 Madrid, Spain \\ 'Dpto. Paleontologia, Facultad de Ciencias Geológicas, Universidad Complutense de Madrid, Ciudad Universitaria, E-28040 Madrid, Spain \\ 'Centro Nacional de Investigación sobre la Evolución Humana, Avenida de la Paz 28, E-\$904 Burgos, Spain
}

\section{A R T I C L E I N F O}

\section{Article history:}

Received 9 November 2007

Accepted 13 August 2008

\section{Keywords:}

Temperature

Rainfall

Seasonality

Quantitative analysis

Herpetof auna

\begin{abstract}
A B S T R A C T
The Gran Dolina cave site is famous for having delivered some of the oldest hominin remains of Western Europe (Homo antecessor, ca. $960 \mathrm{ka}$ ). Moreover, the evidence of lithic industries throughout the long vertical section suggests occupation on the part of hominins from the latest early Pleistocene (levels TD3/4, TD5, and TD6) to the late middle Pleistocene (level TD10). The Gran Dolina Sondeo Sur (TDS) has furnished a great number of small-vertebrate remains; among them some 40,000 bones are attributed to amphibians and squamates. Although they do not differ specifically from the extant herpetofauna of the Iberian Peninsula, the overlap of their current distribution areas (mutual climatic range method) in Spain can provide mean annual temperatures (MAT), the mean temperatures of the coldest (MTC) and warmest (MTW) months, and mean annual precipitation (MAP) estimations for each sub-level, and their change can be studied throughout the sequence. Results from the squamate and amphibian study indicate that during hominin occupation the MAT $\left(10-13^{\circ} \mathrm{C}\right)$ was always slightly warmer than at present in the vicinity of the Gran Dolina Cave, and the MAP $(800-1000 \mathrm{~mm})$ was greater than today in the Burgos area. Climatic differences between "glacial" and "interglacial" phases are poorly marked. Summer temperatures (MTW) show stronger oscillations than winter temperatures (MTC), but seasonality remains almost unchanged throughout the sequence. These results are compared with those for large mammals, small mammals, and pollen analysis, giving a scenario for the palaeoclimatic conditions that occurred during the early to middle Pleistocene in Atapuerca, and hence a scenario for the hominins that once lived in the Sierra de Atapuerca.
\end{abstract}

\section{Introduction}

Chronologically the Gran Dolina sequence corresponds to the presence in the Iberian Peninsula of Homo antecessor (from 1.2 to 0.7 $\mathrm{Ma}$, according to the data from the Sima del Elefante and Gran Dolina) and Homo heidelbergensis (since $0.5 \mathrm{Ma}$, according to the data from the Sima de los Huesos), and so permits identification and comparison of the various climatic conditions that hominins endured when living in the Sierra de Atapuerca. According to herpetofaunal climatic estimations, the presence of hominins at the Sierra de Atapuerca occurs during diverse periods, but still with a warmer and more humid climate than the present one in the Burgos area.
Air temperature and rainfall are fundamental elements of climate and are often considered to be the most important climatic parameters because of the primary role they play in the distribution of vegetation and animal life on Earth. Because amphibians and squamates, as ectothermic vertebrates, are habitat-dependent, the temperature and precipitation in their immediate environment limit their distribution. They can thus contribute to quantitative estimates of past temperatures and precipitation levels. Variations in the composition of a local herpetofauna over time have been used in order to estimate climatic parameters. Such studies can be based primarily on chorological data from extant herpetofaunal populations, because all species present in Pleistocene localities are considered identical to modern species (Barbadillo et al., 1997; Rage and Roček, 2002) and most of them can live at present in the close vicinity of this archaeo-palaeontological locality. A recent study of material from a test-excavation in the Gran Dolina, known as Trinchera Dolina Sondeo Sur (TDS) furnished around 40,000 bones 
of the following amphibians and squamates (Blain, 2005): Triturus sp. sensu stricto (Salamandridae), Alytes obstetricans (Alytidae), Pelobates cultripes (Pelobatidae), Pelodytes punctatus (Pelodytidae), Bufo bufo and Bufo calamita (Bufonidae), Hyla arborea (Hylidae), Rana temporaria, Rana cf. dalmatina, Rana cf. iberica and Pelophylax (ridibunda) sp. (Ranidae), Blanus cinereus (Blanidae), Lacerta s.l. and small-sized indeterminate lacertids (Lacertidae), Anguis fragilis (Anguidae), Natrix natrix, Natrix maura, Coronella austriaca, Coronella cf. girondica and Rhinechis scalaris (Colubridae), Vipera cf. aspis and Vipera cf. latasti (Viperidae). Here we present the first quantitative temperature and precipitation estimates throughout a unique, long, continental hominin-bearing early-middle Pleistocene sequence.

\section{Setting and chronology}

The Sierra de Atapuerca lies about $1080 \mathrm{~m}$ above sea level, dominating the now flat landscape of the Castilian cereal-growing plains irrigated by the River Arlanzon near the village of Ibeas de Juarros, located $14 \mathrm{~km}$ east of the city of Burgos (Fig. 1). Atapuerca is best-known for its complete, long, and stratigraphically well-dated cultural and palaeontological sections in a complex cave system that represents part of the early and part of the middle Pleistocene in the Iberian Peninsula. There are four hominin-bearing localities: Sima del Elefante, which has recently yielded hominin remains (ca. $1.2 \mathrm{Ma}$ ); Gran Dolina, which contains Homo antecessor (ca. $960 \mathrm{ka}$ ); and Sima de los Huesos and Galería, which harbour Homo heidelbergensis (ca. $550 \mathrm{ka}$; see Bermúdez de Castro et al. [2004] and Carbonell et al. [2008] for a comprehensive account). The Gran Dolina (= Trinchera Dolina $=$ TD) remains are among the earliest hominin fossils from Western Europe and were found at the ID6 'Aurora stratum' level (Carbonell et al., 1995; Bermúdez de Castro et al., 1997). Although still ongoing, the archaeological and palaeontological excavations in the Gran Dolina cave (Sierra de Atapuerca, Burgos) have already revealed a long, culturally and palaeontologically rich sequence dated by biostratigraphy, electron spin resonance (ESR), U-series, thermoluminescence ( $T L$ ), infraredstimulated-luminescence (ISRL) analysis, and palaeomagnetic stratigraphy at between roughly $1 \mathrm{Ma}$ and $250 \mathrm{ka}$. Gran Dolina has one of the longest and most continuous vertical profiles. The section, $19 \mathrm{~m}$ thick and divided into 11 lithostratigraphic levels, represents a time span of nearly 700,000 years. The Gran Dolina sequence was partially excavated during a preliminary evaluation of its archaeological and palaeontological richness. This excavation, known as "Trinchera Dolina Sondeo Sur," lasted from 1993 to 1999. ESR dating, U-series, TL, and ISRL analyses date the fossiliferous levels TD6 to TD10 at between ca. $960 \mathrm{ka}$ and $300 \mathrm{ka}$ (Falguères et al., 1999; Berger et al., 2008). The lower part of level 8 (TD8a) ranges from 700 to $500 \mathrm{ka}$, and levels TD10-11 are placed between 400 and $300 \mathrm{ka}$ (Falguères et al., 1999). These results confirm the palaeomagnetic studies of Parés and Pérez-González (1999): the record of the Matuyama-Brunhes palaeomagnetic boundary at

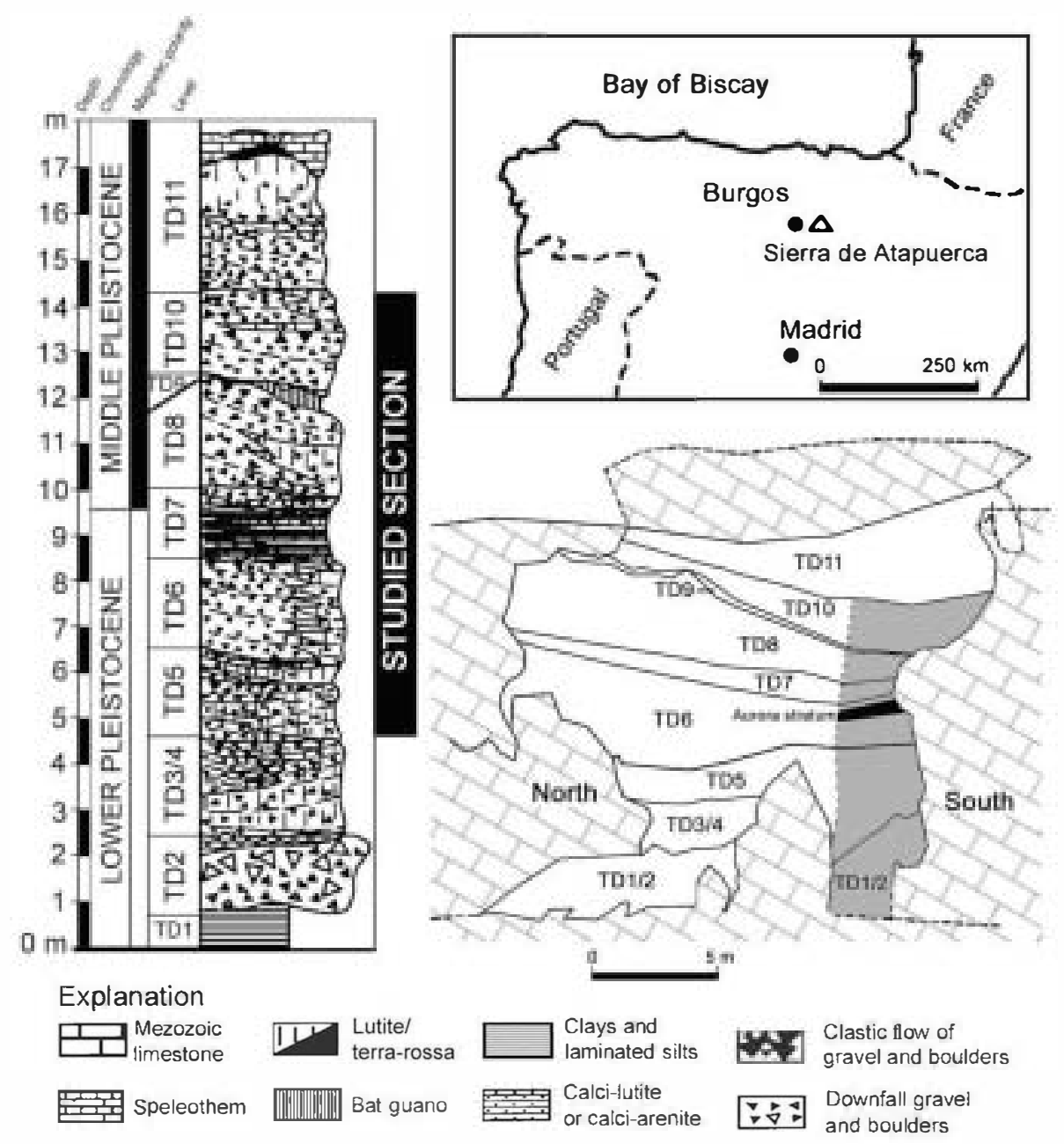

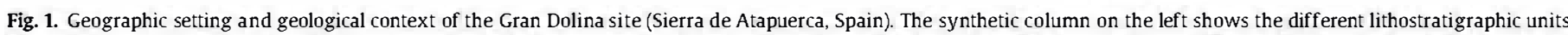

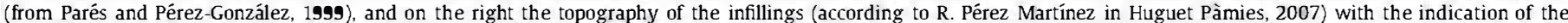
excavation-test called Trinchera Dolina Sondeo Sur (TDS, in grey) and the Aurora stratum (in black). 
level TD7 indicates an age of $780 \mathrm{ka}$. The biostratigraphy confirms an early Pleistocene age for levels TD3/4 to TD6 (see Cuenca-Bescós et al., 1995, 1999 and Cuenca-Bescós and García, 2007).

\section{Materials and methods}

The amphibian and squamate fossil remains used for this study consist of disarticulated elements collected by water-screening during work on TDS. This test-excavation (around $9 \mathrm{~m}^{2}$ ) comprises level TD5 at the bottom to level TD10 at the top, thus lacking levels TD3/4 present in the Gran Dolina North Section (Fig. 1). The excavation was divided into archaeological sub-levels, between 1 and $50 \mathrm{~cm}$ thick. A total of $5596 \mathrm{~kg}$ of sediment was processed. Each sample comprises $1 \mathrm{~m}^{2}$ of a given sub-level. Each sub-level may include up to nine samples depending on the topography of the cave. All the sediment was water-screened using superimposed 10 , 5 , and $0.5-\mathrm{mm}-\mathrm{mesh}$ screens and bagged by square, layer, and excavation sub-levels. In subsequent years, the microfossils were processed, sorted, and classed in large categories at the palaeontology section of the Earth Sciences Department of the University of Zaragoza (Spain). Amphibian and squamate bone remains have been analysed and quantified as part of a Ph.D. dissertation (Blain, 2005). This assemblage includes 39,677 elements that correspond to a minimum of 6,162 individuals, representing at least 22 taxa (Table 1), including newts, toads, and frogs, an amphisbaenian, lacertid, and anguid lizards and several snakes.

Analysis of the overlap of the current distribution of all taxa occurring in a locality or level permits us to calculate potential palaeoclimatic conditions (= mutual climatic range method $=$ MCR). On the basis of the distribution atlas of the Iberian herpetofauna (Pleguezuelos et al., 2004), we simply identify the geographic region (divided into $10 \times 10 \mathrm{~km}$ UTM squares) where all the species present in the locality or in a stratigraphical level currently live (Fig. 2). Careful attention has been paid so that real current distribution corresponds to potential ecological/climatic distribution and was not strongly affected by other limiting or perturbing parameters, as for example urbanism, landscape anthropization, predation, competition with another species, etc.

Climatic factors have been estimated using various climatic maps from Spain (Font Tullot, 1983, 2000) and data provided by Spanish meteorological research station networks over a period of 30 years. Current temperature estimations for each $10 \times 10 \mathrm{~km}$ UTM square have been made to the nearest $0.5^{\circ} \mathrm{C}$ and to the nearest $50 \mathrm{~mm}$ for precipitation. From this variably sized region we can estimate climatic parameters for each $10 \times 10 \mathrm{~km}$ UTM square and compare them with the meteorological station in Burgos (current data from Font Tullot, 2000).

The Burgos area is currently situated at the boundary between two bioclimatic regions: the Mediterranean realm in its major, southern part and the Eurosiberian realm in its northernmost part. Nevertheless, from a climatic point of view, the small altitude variations over most of its territory (700-1000 m) mean that within the Mediterranean part, only the supra-Mediterranean bioclimatic level is represented (Rivas-Martínez, 1986). Burgos possesses a mean annual temperature (MAT) equal to $9.9^{\circ} \mathrm{C}$ (meteorological station of Burgos air base, $881 \mathrm{~m}$ above sea level, Fig. 3). The MTC (January) is $2.6^{\circ} \mathrm{C}$ with absolute minima reaching $-22{ }^{\circ} \mathrm{C}$, making Burgos one of the coldest cities of the Iberian Peninsula (Font Tullot, 2000). The MTW (July) is $18.4^{\circ} \mathrm{C}$ with absolute maxima reaching $38^{\circ} \mathrm{C}$ (in July and August). The MAP is $572 \mathrm{~mm}$ and mainly occurs during winter and spring (Font Tullot, 2000).

Because there are a large number of climatic parameters, climatologists usually use numerical indexes to define the various types of climate. As far as temperature is concerned, continentality and oceanity indices are used. Continentality indicates the influence on climate of the location within a continent. Continental locations typically have larger temperature ranges and (possibly) drier conditions than maritime locations. Such indices may be applied over a long temporal sequence to evaluate the changes in climate linked with variations in sea-level or marine influence (such as Atlantic Ocean circulation or southward shift of the polar front; see Pross and Klotz, 2002). To evaluate changes in continentality (=temperature range), the seasonality index of Schrepfer (1925), $C=(800 A / 7 \varphi)-14$, was applied. In this index, $\mathrm{A}=$ difference between the MTW and MTC (both in ${ }^{\circ} \mathrm{C}$ ) and $\varphi=$ geographical latitude ( $\varphi$ Burgos air base $=42.357628^{\circ}$ ). High seasonality is characterized by high $C$ values, whereas more equable temperature conditions have lower $C$ values. The Schrepfer Index in Burgos is currently 28.6.

\section{Factors that may influence accumulation of remains}

Traditionally, bone-accumulating predators are the main factor affecting small-vertebrate assemblages in caves (Andrews, 1990). However, at least in the Iberian Peninsula, predators that occasionally catch amphibians and/or squamates are considered opportunistic, and their accumulations are qualitatively and quantitatively representative of the immediate environment surrounding the cave. At Gran Dolina, it has been shown that the primary agents of small-mammal deposition are owls; secondary agents are mammalian carnivores, self-entries, water flows, mudflows, and other agents (Fernández-Jalvo and Andrews, 1992; Fernández-Jalvo, 1996). In the case of amphibians, previous study by Pinto Llona and Andrews (1999) have suggested that remains of ID3/4 and TD5 come from predation by small carnivores; however, of the material studied here, only a few elements show such strong evidence of digestion similar to that made by carnivores (Blain, 2005; Blain et al., 2008a). As suggested by Blain et al. (2008a), the origin of the herpetofauna in Gran Dolina may at least be dual, with some accumulated by predators (bird of prey, small carnivores, etc. as suggested by Pinto Llona and Andrews, 1999) and some (such as Bufo calamita representing more than $60 \%$ of total remains) from mortality while frequenting the cave.

In this way, factors that influence the morphology of the entrance or create ecological barriers in the vicinity of the cave must be considered. As suggested by Blain (2005), the morphology of the cave entrance seems to be essential in the composition of the herpetofauna assemblages. In vertical fissure localities, for example Almenara-Casablanca-3 (Blain et al., 2007) or Cueva Victoria (Blain et al., 2008b), both in Spain, squamates represent more than $90 \%$ of the herpetofauna (predominating rocky small lacertids, geckos, etc.). On the other hand, at localities with a typical "cave entrance" such as Gran Dolina, anurans represent 90\% of the total herpetofauna (Blain et al., 2008a), because they may frequent the entrance in search of the mildest or moistest conditions during a portion of the year (wintering or aestivation).

Levels ID5 and TD6 correspond to exogenous sediments with a contact to the exterior. The entrance must have been rather large, because hominins are shown to be responsible for the accumulation of large mammals (including human remains) that exhibit intentional fractures and cut-marks (Fernández-Jalvo, 1996; Díez et al., 1999). Carnivores have secondary impact on the bones abandoned by hominins (Rosell et al., 1998). During 1D9, the cave was partially closed, but in TD10 the cave opened again with the collapse of the roof (Parés and Pérez-González, 1999). In TD10, large mammal bone accumulations have an anthropogenic origin (Díez and Rosell, 1998), and carnivores use the site when hominins are away (Esteban, 1996).

In conclusion, because accumulations are the result of various independent factors (predation, self-entries, etc.) that probably occur over a very long period of time (thousands years for each sublevel), and because there is no evidence of ecological or physical 
Table 1

-ccurence of amphibians and squamate repriles in the Gran Dolina sequence by sublevel (after Blain, 2005)

\begin{tabular}{|c|c|c|c|c|c|c|c|c|c|c|c|c|c|c|c|c|c|c|c|c|c|}
\hline Level & $\begin{array}{l}\text { I Sub- } \\
\text { level }\end{array}$ & $\begin{array}{l}\text { Triturus } \\
\text { sp. }\end{array}$ & $\begin{array}{l}\text { Alytes } \\
\text { obstetricans }\end{array}$ & $\begin{array}{l}\text { Pelobates } \\
\text { s cultripes }\end{array}$ & $\begin{array}{l}\text { Pelodytes } \\
\text { punctatus }\end{array}$ & $\begin{array}{l}\text { Bufo } \\
\text { bufo }\end{array}$ & $\begin{array}{l}\text { Bufo } \\
\text { calamita }\end{array}$ & $\begin{array}{l}\text { Hyia } \\
\text { arborea }\end{array}$ & $\begin{array}{l}\text { Rana } \\
\text { sp. }\end{array}$ & $\begin{array}{l}\text { Peloph yiax } \\
\text { (ridibunda) sp. }\end{array}$ & $\begin{array}{l}\text { Bianus } \\
\text { cinereus }\end{array}$ & $\begin{array}{l}\text { Lacerta } \\
\text { s.l. }\end{array}$ & $\begin{array}{l}\text { Lacertidae } \\
\text { indet. }\end{array}$ & $\begin{array}{l}\text { Anguis } \\
\text { fragilis }\end{array}$ & $\begin{array}{l}\text { Natrix } \\
\text { maura }\end{array}$ & $\begin{array}{l}\text { Natrix } \\
\text { natrix }\end{array}$ & $\begin{array}{l}\text { Coronellia } \\
\text { austriack }\end{array}$ & $\begin{array}{l}\text { Coronella cf. } \\
\text { girondica }\end{array}$ & $\begin{array}{l}\text { Rhinechis } \\
\text { scalaris }\end{array}$ & $\begin{array}{l}\text { Viper cf. } \\
\text { aspis }\end{array}$ & $\begin{array}{l}\text { Vipera cf. } \\
\text { iatusti }\end{array}$ \\
\hline TD10 & T0 & & $x$ & & $x$ & $x$ & $x$ & & $x$ & & & & & & & & & & & & \\
\hline & $\mathrm{T} 1$ & & $\mathbf{x}$ & & $\mathbf{x}$ & $x$ & $\mathbf{x}$ & & $\mathbf{x}$ & & & & $\mathbf{x}$ & & & & & & & $\mathbf{x}$ & \\
\hline & T2 & & $\mathbf{x}$ & & & $\mathrm{x}$ & $\mathbf{x}$ & & $\mathbf{x}$ & & & & $\mathbf{x}$ & & $\mathbf{x}$ & & & & & $\mathbf{x}$ & \\
\hline & T3 & & & & & $\mathrm{x}$ & & & $\mathbf{x}$ & & & & & & & & & & & & \\
\hline & T4 & & $x$ & & $\mathbf{x}$ & $\mathbf{x}$ & $\mathbf{x}$ & & $\mathbf{x}$ & & & & $\mathbf{x}$ & & & & & & & $\mathbf{x}$ & \\
\hline & T5 & & $x$ & & $\mathbf{x}$ & $\mathbf{x}$ & $x$ & & $\mathbf{x}$ & & & & $\mathbf{x}$ & & & & & & & $\mathbf{x}$ & \\
\hline & T6 & & $\mathbf{x}$ & & $\mathbf{x}$ & $\mathbf{x}$ & $x$ & $\mathbf{x}$ & $\mathbf{x}$ & & & & $\mathbf{x}$ & & & & & & & $\mathbf{x}$ & \\
\hline & T8 & & $\mathbf{x}$ & & $\mathbf{x}$ & $\mathbf{x}$ & $\mathbf{x}$ & & $\mathbf{x}$ & & & & $\mathbf{x}$ & & & & & & & & \\
\hline & T9 & & $\mathbf{x}$ & $\mathbf{x}$ & & $x$ & $\mathbf{x}$ & & $\mathrm{x}$ & & & & $\mathbf{x}$ & & & & & & & $\mathbf{x}$ & \\
\hline & T10 & & $\mathbf{x}$ & & $\mathbf{x}$ & $\mathbf{x}$ & $\mathbf{x}$ & & $\mathrm{x}$ & & & & $\mathrm{x}$ & & & & & & & $\mathbf{x}$ & \\
\hline & T12 & & $\mathbf{x}$ & & $\mathbf{x}$ & $\mathbf{x}$ & $\mathbf{x}$ & & $x$ & & & & $\mathbf{x}$ & & $\mathbf{x}$ & & $\mathbf{x}$ & & & $\mathbf{x}$ & \\
\hline & T15 & & $x$ & & $x$ & $x$ & $x$ & & $x$ & & & & $x$ & & & & & & & $x$ & \\
\hline & T16 & & $\mathbf{x}$ & & $\mathbf{x}$ & $\mathbf{x}$ & $\mathbf{x}$ & & $\mathbf{x}$ & & & & $\mathbf{x}$ & & & & & & & $\mathbf{x}$ & $\mathbf{x}$ \\
\hline & T17 & & $x$ & $x$ & $x$ & $x$ & $\mathbf{x}$ & $x$ & $x$ & & & & $x$ & & & & & & & $\mathbf{x}$ & \\
\hline & T18 & & $\mathbf{x}$ & & $x$ & $x$ & $x$ & & $x$ & $\mathbf{x}$ & & & $\mathbf{x}$ & & & & $\mathbf{x}$ & & & $x$ & \\
\hline & T19 & & $\mathbf{x}$ & $\mathbf{x}$ & $\mathbf{x}$ & $\mathbf{x}$ & $\mathbf{x}$ & $\mathbf{x}$ & $\mathbf{x}$ & & & & $\mathbf{x}$ & & $\mathbf{x}$ & & $x$ & & & $\mathbf{x}$ & \\
\hline & T20 & & $x$ & $\mathbf{x}$ & $\mathbf{x}$ & $x$ & $x$ & $\mathbf{x}$ & $\mathbf{x}$ & & & & $\mathbf{x}$ & & $\mathbf{x}$ & & $x$ & & $\mathbf{x}$ & $\mathbf{x}$ & \\
\hline & $\mathrm{T} 21$ & & $\mathbf{x}$ & $\mathbf{x}$ & $\mathbf{x}$ & $x$ & $x$ & & $\mathbf{x}$ & & & & $\mathbf{x}$ & $\mathbf{x}$ & $\mathbf{x}$ & & $\mathbf{x}$ & & $\mathbf{x}$ & $\mathbf{x}$ & \\
\hline & T22 & & $\mathbf{x}$ & $\mathbf{x}$ & $\mathbf{x}$ & $\mathbf{x}$ & $\mathbf{x}$ & $\mathbf{x}$ & $\mathbf{x}$ & $\mathbf{x}$ & & & $\mathbf{x}$ & & $\mathbf{x}$ & & $x$ & $x$ & $x$ & $\mathbf{x}$ & $\mathbf{x}$ \\
\hline TD8b & b T24 & & & & & & $\mathbf{x}$ & & & & & & $\mathbf{x}$ & & & & & & & & \\
\hline & T26 & & & & & & $\mathbf{x}$ & & & & & & & & & & & & & & \\
\hline TD8a & a T27 & & $\mathbf{x}$ & $\mathbf{x}$ & $\mathbf{x}$ & $\mathbf{x}$ & $\mathbf{x}$ & $\mathbf{x}$ & $\mathbf{x}$ & & $\mathbf{x}$ & $\mathbf{x}$ & $\mathbf{x}$ & & $\mathbf{x}$ & $\mathbf{x}$ & $\mathbf{x}$ & & $\mathbf{x}$ & $\mathbf{x}$ & \\
\hline & T28 & & $x$ & $\mathbf{x}$ & $x$ & $\mathbf{x}$ & $x$ & $\mathbf{x}$ & $\mathbf{x}$ & $\mathbf{x}$ & & $\mathbf{x}$ & $\mathbf{x}$ & & & $\mathbf{x}$ & $\mathbf{x}$ & & & $\mathbf{x}$ & \\
\hline TD7 & T30 & & $x$ & & $\mathbf{x}$ & $x$ & $x$ & & $x$ & & & $x$ & $x$ & & & & $x$ & & $\mathrm{x}$ & & \\
\hline TD6 & T32 & & $x$ & & $x$ & $x$ & $x$ & & $x$ & & & $x$ & $x$ & & & $\mathbf{x}$ & $x$ & & & $x$ & \\
\hline & T33 & & $x$ & $\mathbf{x}$ & $\mathbf{x}$ & & $x$ & & $\mathbf{x}$ & & & $\mathbf{x}$ & $\mathbf{x}$ & $\mathbf{x}$ & & $\mathbf{x}$ & $x$ & & & $\mathbf{x}$ & \\
\hline & T34 & & $x$ & & $x$ & $\mathrm{x}$ & $x$ & & $\mathbf{x}$ & & & $\mathbf{x}$ & $\mathbf{x}$ & & & $\mathbf{x}$ & & & & $\mathbf{x}$ & \\
\hline & T35 & & x & $\mathbf{x}$ & $\mathbf{x}$ & $x$ & $\mathbf{x}$ & & $\mathbf{x}$ & & & $\mathbf{x}$ & $\mathbf{x}$ & $\mathbf{x}$ & & $\mathbf{x}$ & $\mathbf{x}$ & & $\mathbf{x}$ & $\mathbf{x}$ & \\
\hline & T36 & & $\mathbf{x}$ & $\mathbf{x}$ & $x$ & $x$ & $x$ & & $\mathrm{x}$ & & & $\mathbf{x}$ & $\mathbf{x}$ & $\mathbf{x}$ & & & $\mathbf{x}$ & & $x$ & $x$ & \\
\hline & T37 & & $x$ & $\mathbf{x}$ & $x$ & $x$ & 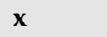 & & $x$ & & & $\mathbf{x}$ & $\mathbf{x}$ & & & $\mathbf{x}$ & $x$ & & $x$ & $x$ & \\
\hline & T38 & & $\mathbf{x}$ & & $\mathbf{x}$ & $\mathbf{x}$ & $\mathbf{x}$ & & $\mathbf{x}$ & & & $\mathbf{x}$ & $\mathbf{x}$ & & & & & & & & \\
\hline & T40 & & $x$ & $\mathbf{x}$ & $\mathbf{x}$ & & $\mathbf{x}$ & & $\mathbf{x}$ & & & & $\mathbf{x}$ & & & & $\mathbf{x}$ & & & $\mathbf{x}$ & \\
\hline & T41 & & $\mathbf{x}$ & $x$ & $\mathbf{x}$ & & $x$ & & $\mathrm{x}$ & & & & $\mathbf{x}$ & & & & $\mathbf{x}$ & & & $x$ & \\
\hline & T42 & & & & & & $\mathbf{x}$ & & & & & & $\mathbf{x}$ & & & & $\mathbf{x}$ & & & & \\
\hline & T43 & & $\mathbf{x}$ & $\mathbf{x}$ & $\mathbf{x}$ & $\mathbf{x}$ & $x$ & & $\mathbf{x}$ & $\mathbf{x}$ & & $\mathbf{x}$ & $x$ & $\mathbf{x}$ & & $\mathbf{x}$ & $\mathbf{x}$ & & $\mathrm{x}$ & $\mathbf{x}$ & \\
\hline & T44 & & $\mathbf{x}$ & $x$ & $x$ & $\mathbf{x}$ & $\mathbf{x}$ & & $x$ & & & $\mathbf{x}$ & $x$ & $x$ & & $\mathbf{x}$ & $x$ & & $x$ & $x$ & \\
\hline & T45 & & $\mathbf{x}$ & $\mathbf{x}$ & $\mathbf{x}$ & & $\mathbf{x}$ & & $\mathbf{x}$ & & & $\mathbf{x}$ & $\mathbf{x}$ & $\mathbf{x}$ & & $\mathbf{x}$ & $\mathbf{x}$ & & $\mathbf{x}$ & $\mathbf{x}$ & \\
\hline & T47 & & $\mathbf{x}$ & $\mathbf{x}$ & & $\mathrm{x}$ & $\mathbf{x}$ & & $\mathbf{x}$ & & & $\mathbf{x}$ & $\mathbf{x}$ & $\mathbf{x}$ & & & $\mathbf{x}$ & & $\mathbf{x}$ & $\mathbf{x}$ & \\
\hline & T48 & & $x$ & $\mathbf{x}$ & $\mathbf{x}$ & $\mathrm{x}$ & $\mathbf{x}$ & & $\mathbf{x}$ & & & $\mathbf{x}$ & $\mathbf{x}$ & $\mathbf{x}$ & & & $\mathbf{x}$ & & $\mathbf{x}$ & $\mathbf{x}$ & \\
\hline & T49 & & $x$ & & $\mathrm{x}$ & & $\mathbf{x}$ & & $x$ & & & $\mathbf{x}$ & $\mathrm{x}$ & $x$ & & & $\mathbf{x}$ & & & $\mathbf{x}$ & \\
\hline & T50 & & $x$ & $\mathbf{x}$ & $x$ & $\mathbf{x}$ & $\mathbf{x}$ & & 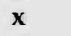 & & & $\mathbf{x}$ & $\mathbf{x}$ & $x$ & & & $\mathbf{x}$ & & $\mathbf{x}$ & $x$ & \\
\hline & T51 & $\mathbf{x}$ & $x$ & & $\mathbf{x}$ & $\mathrm{x}$ & $x$ & & $\mathbf{x}$ & & & $\mathbf{x}$ & $\mathbf{x}$ & $\mathbf{x}$ & & & $x$ & & & & \\
\hline & T52 & & $x$ & & $\mathbf{x}$ & $x$ & $\mathbf{x}$ & & $\mathbf{x}$ & & & $\mathbf{x}$ & $\mathbf{x}$ & $\mathbf{x}$ & & & $\mathbf{x}$ & & & & \\
\hline & T53 & & $x$ & & $\mathbf{x}$ & $\mathbf{x}$ & $\mathbf{x}$ & & $\mathbf{x}$ & & & $\mathbf{x}$ & $\mathbf{x}$ & $\mathbf{x}$ & & & $\mathbf{x}$ & & & $\mathbf{x}$ & \\
\hline & T54 & & $\mathbf{x}$ & & $\mathbf{x}$ & $\mathbf{x}$ & $\mathbf{x}$ & & $\mathbf{x}$ & $\mathbf{x}$ & & $\mathbf{x}$ & $\mathbf{x}$ & & & & $x$ & & & $\mathbf{x}$ & \\
\hline & T55 & & $\mathbf{x}$ & & & $\mathbf{x}$ & $\mathbf{x}$ & & $\mathbf{x}$ & & & & $\mathbf{x}$ & & & & $x$ & & & $\mathbf{x}$ & \\
\hline
\end{tabular}




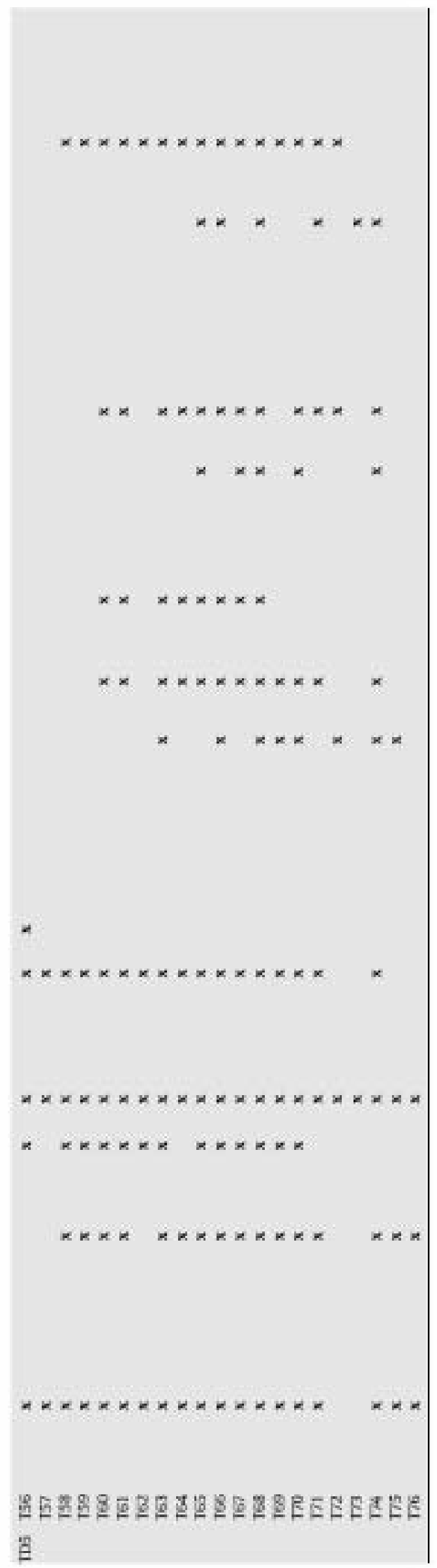

barriers that may modify the access to the cave for amphibians and squamate reptiles (other than in the sterile bat guano level TD9), we consider the fossil assemblages, at least from a qualitative point of view, to be representative of the local climatic conditions. Regardless, because the MCR method used here only deals with presence/absence and because various species may have the same ecological/climatic requirements (and so geographical distribution), if any species are lacking, the estimation may be more imprecise but not necessarily wrong.

\section{Evolution of climatic parameters in Gran Dolina}

For the entire sequence, the overlap of the geographic ranges of the species present as fossils (Fig. 3) represents a variably sized area principally composed of the Pyrenean foothills (Catalonia, Aragon, and the Basque Country) and the massif of Montseny (Barcelona). From a climatic point of view, this corresponds to a rather cool and humid area characteristic of the transition between the Eurosiberian and Mediterranean realms. The climate is slightly continental (winter-summer amplitude of $15^{\circ} \mathrm{C}$ ) with the MTC (January) mainly lower than $6^{\circ} \mathrm{C}$ and the MTW (July) between 16 and $24^{\circ} \mathrm{C}$, with significant rainfall during winter and autumn (with the exception of Girona), as well as a rather humid summer (Fig. 3).

The overlap of different species for different levels range over a large area that provides the coldest temperatures of the sequence (TD5 [sublevels T58-T74], TD6 [T49 and T51-T55], and TD10 [T18-T0]) to an area including only Catalonia that suggests warmer temperatures in the lower part of TD10 (sublevel T21) and the upper part of TD6 (sub-levels T33, T35, T36, T37, T40, T41, T43, T44, T45, T47, T48, and T50). For precipitation, the lowest values from level TD10 (sublevels T1, T4, T5, T6, T9, T10, T15, and T16) come from overlaps indicating less than $10 \times 10 \mathrm{~km}$ UTM squares in areas of high rainfall. As shown in Table 2 and Fig. 4, for a few levels there are no data. This occurs when there are too few taxa identified in a sub-level and, therefore, the overlap is very large and not climatically significant, as in layer TD8b. On the other hand, for level ID8a and the base of TD10, it also occurs when some overlaps are impossible, mainly because the current distribution of Hyla arborea does not intersect with that of other species.

All MAT estimations (Table 2) fall in the interval $\left(9-13^{\circ} \mathrm{C}\right.$ ) proposed by Blain (2005) from the distribution data of extant amphibians and squamate reptiles. The absence of the thermophilous ladder snake (Rhinechis scalaris) was put in relation with probable cooler periods (MAT $<10^{\circ} \mathrm{C}$ ) in the top of TD5, the base of TD6, and all TD10 (Table 1). In other levels, the presence of the ladder snake (MAT $>10^{\circ} \mathrm{C}$ ) together with the brown frog's representatives (Rana sp.; MAT $<12{ }^{\circ} \mathrm{C}$ ) suggests a warm-temperate climate. For rainfall, the presence of brown frog representatives (MAP $>600 \mathrm{~mm}$ ) together with the western spadefoot toad (Pelobates cultripes; MAP mainly lower than $900 \mathrm{~mm}$ ) suggests subhumid to humid conditions. In the base of TD10 (sublevels T16 and T22; Table 1), the occurrence of the Lataste's viper (Vipera latasti) suggests warm and dry conditions (MAT $>12-13^{\circ} \mathrm{C}$ and MAP $<600 \mathrm{~mm}$ ), and the Mediterranean worm lizard (Blanus cireneus) in TD8a (sub-level T27) may indicate the warmest time of the Gran Dolina sequence (MAT close to the $13^{\circ} \mathrm{C}$ ).

According to the present temperature calculations, "cold" and "warm" periods are well emphasized. Cooler periods correspond to the upper part of level TD5, the lower part of TD6, and the upper part of TD10, whereas warm-temperate periods are the middle part of TD5, the upper part of TD6, and the lower part of TD10. These variations are consistent with the observed quantitative variations of the percentage of Mediterranean taxa throughout the sequence, where higher percentages (= warmer periods) come from the base of TD5, the upper part of TD6, and TD8a (Blain, 2005). Generally, summer temperatures (as represented by the MTW) show stronger 


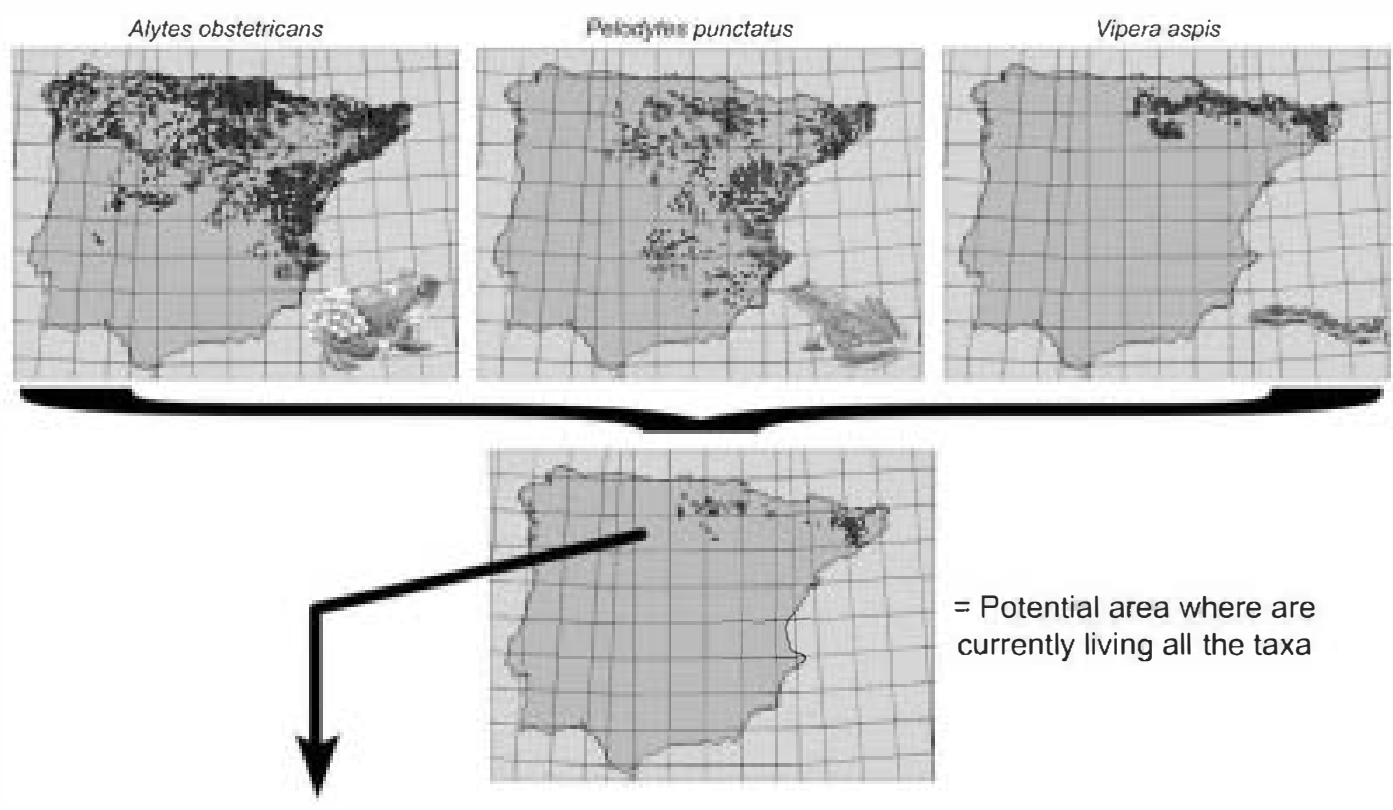

Climatic criteria of each $10 \times 10 \mathrm{~km}$ UTM square

Mean annual temperature

Mean temperature of the coldest

and warmest month

Mean annual precipitations

Bioclimatic level

etc...

3

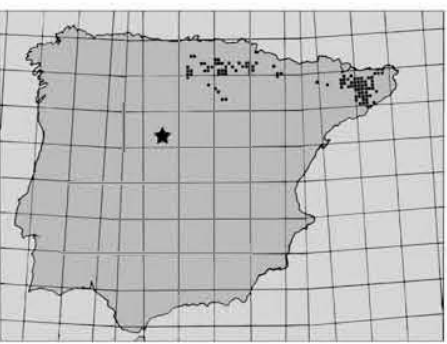

Statistical treatment

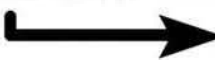

Comparison with locality $10 \times 10 \mathrm{~km}$ UTM square

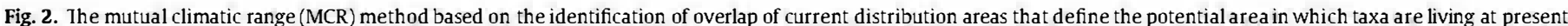

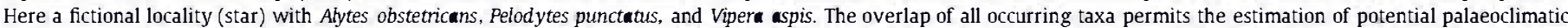
conditions occurring during the locality/layer formation based on present conditions of the geographic overlap. Current distribution af ter Pleguezuelos et al. (2004).

oscillations than winter temperatures (as represented by the MTC), but seasonality stays almost unchanged throughout the sequence, being slightly stronger during warmer periods. This may be a peculiarity of Pleistocene climatic changes in the Iberian Peninsula, whereas in North Europe cold and temperate stages are characterized by strong variations in winter temperatures in combination with relatively constant summer temperatures (Pross and Klotz, 2002).

Rainfall (MAP) is abundant throughout the sequence with some dryer short periods in particular in the middle part of level TD10. The higher variability of rainfall in level TD10 is not concordant with quantitative variation in hydrophilous taxa throughout the sequence as suggested by Blain et al. (2008a), but on the other hand it does not agree with the extreme environmental dryness suggested by Cuenca-Bescós et al. (2005) either. Blain et al. (2008a) suggested that warm-temperate periods at Gran Dolina have a dryer landscape and colder periods may have been more humid and woody. Climatic parameters calculated here show that the truth may be more complex than this and that while warmer periods may have had a higher rainfall, colder periods may have been characterized by rainfall irregularity rather than by low values. Nevertheless, dryness of the landscape is not only determined by annual rainfall and there may be other factors to consider, such as the distribution of precipitation during the year and its intensity.

\section{Comparisons with other proxies}

Various proxies have been used to infer palaeoclimatic indications along the Gran Dolina sequence. Palynological studies at Gran Dolina (García Antón and Sainz Ollero, 1991; García Antón, 1995) have documented varyingly rich pollen spectra. The TD5, TD6, and ID7 pollen spectra are very poor, but document a more or less open forest cover with Quercus, Cupressaceae, and some Mediterranean floristic elements (Olea, Pistacea), suggesting alternations of cold and temperate periods. TD8a characterizes a warm-temperate humid period, with a Quercus forest accompanied by Castanea and sporadically by Fagus, Alnus, Pistacea, and Ericaceae. In the upper part of TD10, Pinus becomes predominant and may indicate a cold and dry period.

Small-mammal associations and the evolution of their diversity through the sequence (Cuenca-Bescós et al., 1995, 2005; López Antoñanzas and Cuenca Bescós, 2002) suggest that lower TD5 may represent a continental, dry, and cold climate; that upper TD5 and TD6 fauna reflects a complex interglacial period with fluctuations in the degree of relative humidity; that the TD8b corresponds to a relatively cold period; and finally, that TD8a and TD10 reflect another interglacial period with slight oscillations in relative moisture.

The large mammal record has a less precise resolution in the excavation-test, but gives valuable data for the potential climate in 

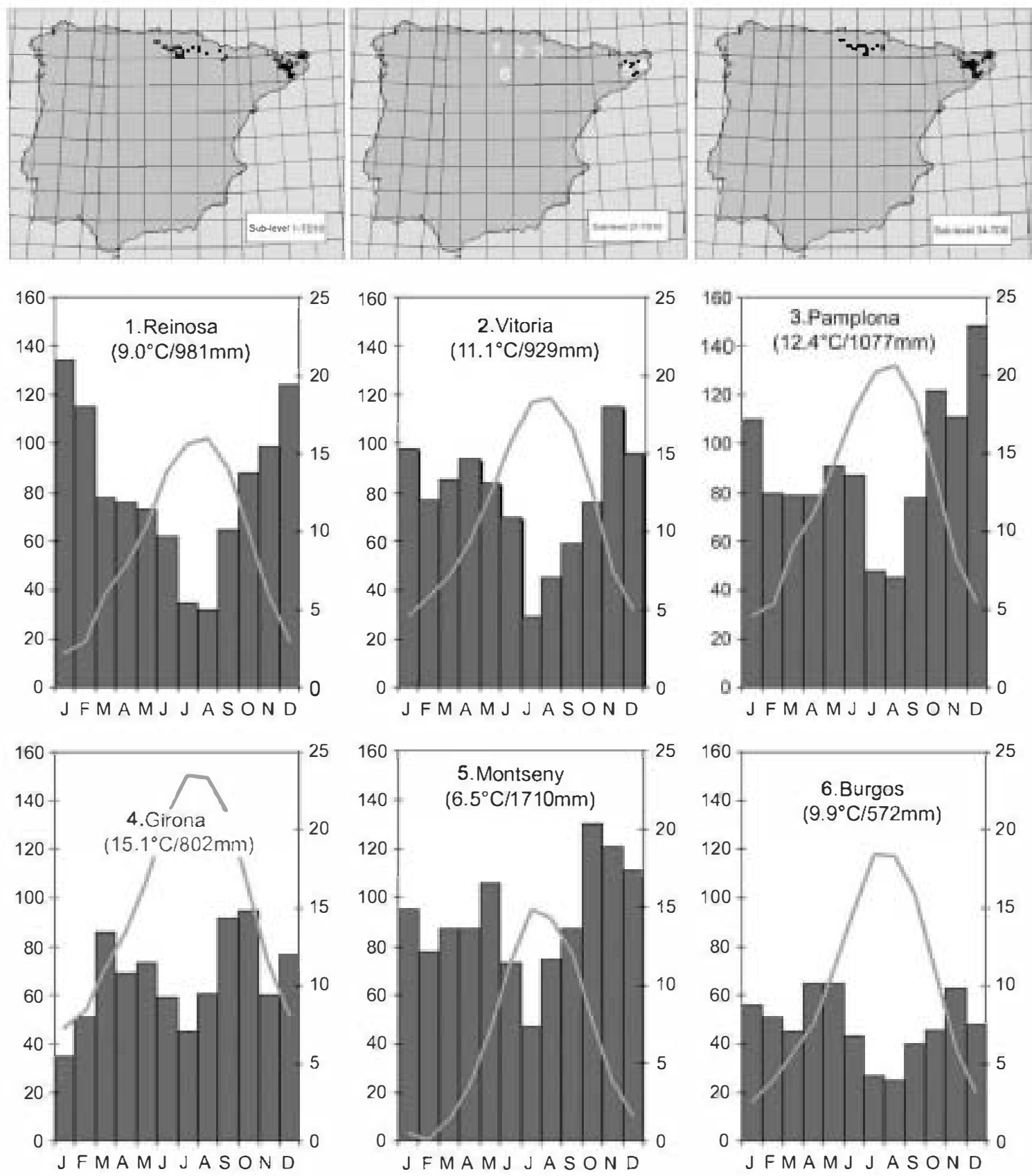

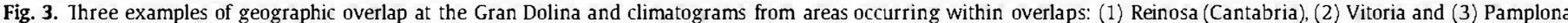

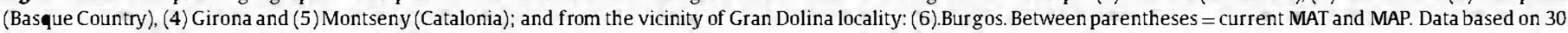
years record after Font Tullot (2000).

the Sierra de Atapuerca during the formation of the Gran Dolina infillings. Accordingly, the pollen, small mammal, and large mammal records at Gran Dolina are compared to the herpetofauna (Fig. 5); keeping in mind that, as said above, aridity of a landscape cannot be directly linked with MAP, mainly because it takes only a few months of drought to strongly affect vegetation.

TD5

Amphibian and squamate reptile proxies document an open landscape (Blain et al., 2008a) and suggest the evolution from temperate-wet to cold and more humid conditions (Fig. 5). Different disciplines agree in characterizing TD5 as a complex period, evolving toward colder humid conditions. A decrease in temperature towards the top of TD5, as suggested by García Antón and Sainz Ollero (1991), is in accordance with the absence of Rhinechis scalaris, a Mediterranean snake present in the lower part of TD5 (Table 1).

\section{TD6}

Amphibians and squamates suggest an evolution from a cold to a warm climate during TD6, with an increase in open-dry habitats toward the top (Blain et al., 2008a). Such an increase in temperature is concordant with results from other disciplines. The presence of Mediterranean taxa towards the top of TD6 suggests a temperate climate at the Aurora stratum and above it (sub-levels T32-T43), coinciding with the presence of temperate mammals 
Table 2

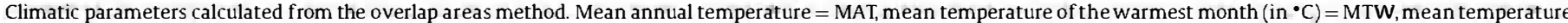

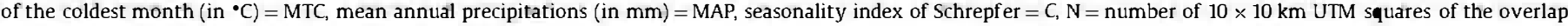
$\mathrm{SD}=$ standard deviation, $\min =$ minimum, $\max =$ maximum

\begin{tabular}{|c|c|c|c|c|c|c|c|c|c|c|c|c|c|c|c|c|c|c|c|}
\hline \multirow[t]{2}{*}{ Level } & \multirow[t]{2}{*}{ Sub-level } & \multirow{2}{*}{$\frac{}{N}$} & \multicolumn{4}{|l|}{ MAT } & \multicolumn{4}{|l|}{ MTC } & MTW & & & & MAP & & & & C \\
\hline & & & MEAN & SD & $\min$ & $\max$ & MEAN & SD & $\min$ & $\max$ & MEAN & SD & $\min$ & $\max$ & MEAN & SD & $\min$ & $\max$ & \\
\hline TD10 & T0 & 63 & 11.45 & 1.94 & 6.0 & 14.0 & 3.49 & 1.95 & -1.0 & 7.5 & 19.59 & 1.67 & 15.0 & 22.5 & 975 & 206 & 550 & 1500 & 29.4 \\
\hline & $\mathrm{T} 1$ & 50 & 11.60 & 1.83 & 5.5 & 14.0 & 3.70 & 2.00 & -0.5 & 7.5 & 19.90 & 1.44 & 16.0 & 22.0 & 876 & 153 & 600 & 1200 & 29.7 \\
\hline & $\mathrm{T} 2$ & 68 & 11.29 & 2.06 & 5.0 & 14.0 & 3.74 & 2.13 & -1.0 & 7.5 & 19.56 & 1.53 & 16.0 & 22.5 & 990 & 202 & 600 & 1500 & 28.7 \\
\hline & T3 & no & & & & & no data & & & & no data & & & & no data & & & & \\
\hline & $\mathrm{T} 4$ & 50 & 11.60 & 1.83 & 5.5 & 14.0 & 3.70 & 2.00 & -0.5 & 7.5 & 19.90 & 1.44 & 16.0 & 22.0 & 876 & 153 & 600 & 1200 & 29.7 \\
\hline & T5 & 50 & 11.60 & 1.83 & 5.5 & 14.0 & 3.70 & 2.00 & -0.5 & 7.5 & 19.90 & 1.44 & 16.0 & 22.0 & 876 & 153 & 600 & 1200 & 29.7 \\
\hline & T6 & 14 & 11.75 & 0.78 & 10.5 & 12.5 & 4.25 & 0.73 & 3.0 & 5.0 & 19.61 & 1.21 & 17.0 & 20.5 & 811 & 121 & 600 & 1000 & 27.4 \\
\hline & $\mathrm{T} 8$ & 63 & 11.45 & 1.94 & 6.0 & 14.0 & 3.49 & 1.95 & -1.0 & 7.5 & 19.59 & 1.67 & 15.0 & 22.5 & 975 & 206 & 550 & 1500 & 29.4 \\
\hline & T9 & 22 & 12.68 & 1.33 & 10.0 & 14.5 & 4.16 & 1.98 & 1.0 & 8.0 & 21.02 & 1.20 & 18.0 & 22.5 & 864 & 126 & 600 & 1100 & 31.5 \\
\hline & T10 & 50 & 11.60 & 1.83 & 5.5 & 14.0 & 3.70 & 2.00 & -0.5 & 7.5 & 19.90 & 1.44 & 16.0 & 22.0 & 876 & 153 & 600 & 1200 & 29.7 \\
\hline & $\mathrm{T} 12$ & 20 & 11.28 & 1.92 & 6.0 & 14.0 & 2.93 & 1.91 & -0.5 & 5.5 & 18.98 & 1.63 & 16.0 & 22.0 & 923 & 122 & 600 & 1100 & 29.3 \\
\hline & T15 & 50 & 11.60 & 1.83 & 5.5 & 14.0 & 3.70 & 2.00 & -0.5 & 7.5 & 19.90 & 1.44 & 16.0 & 22.0 & 876 & 153 & 600 & 1200 & 29.7 \\
\hline & T16 & 2 & 11.75 & 0.35 & 11.5 & 12.0 & 3.75 & 0.35 & 3.5 & 4.0 & 19.75 & 0.35 & 19.5 & 20.0 & 750 & 212 & 600 & 900 & 29.2 \\
\hline & T17 & no & & & & & no data & & & & no data & & & & no data & & & & \\
\hline & T18 & 22 & 11.18 & 1.92 & 6.0 & 14.5 & 2.98 & 1.89 & -0.5 & 6.0 & 19.32 & 1.51 & 16.5 & 22.0 & 955 & 116 & 650 & 1200 & 30.1 \\
\hline & T19 & no & & & & & no data & & & & no data & & & & no data & & & & \\
\hline & $\mathrm{T} 20$ & no & & & & & no data & & & & no data & & & & no data & & & & \\
\hline & T21 & 8 & 12.56 & 1.18 & 10.5 & 14.5 & 3.75 & 1.87 & 0.5 & 6.0 & 20.25 & 1.16 & 18.0 & 22.0 & 981 & 46 & 900 & 1050 & 30.5 \\
\hline & $\mathrm{T} 22$ & no & & & & & no data & & & & no data & & & & no data & & & & \\
\hline TD8b & $\mathrm{T} 24$ & no & & & & & no data & & & & no data & & & & no data & & & & \\
\hline & T26 & no & & & & & no data & & & & no data & & & & no data & & & & \\
\hline TD8a & $\mathrm{T} 27$ & no & & & & & no data & & & & no data & & & & no data & & & & \\
\hline & T28 & no & & & & & no data & & & & no data & & & & no data & & & & \\
\hline TD7 & T30 & 15 & 12.07 & 1.08 & 10.0 & 14.0 & 3.43 & 1.46 & 1.0 & 5.5 & 20.27 & 0.80 & 18.5 & 22.0 & 907 & 169 & 600 & 1100 & 31.4 \\
\hline TD6 & T32 & 19 & 11.58 & 1.46 & 8.5 & 14.0 & 3.13 & 2.10 & -0.5 & 6.0 & 18.50 & 2.05 & 16.0 & 22.0 & 976 & 103 & 650 & 1100 & 27.5 \\
\hline & T33 & 8 & 12.56 & 1.18 & 10.5 & 14.5 & 3.75 & 1.87 & 0.5 & 6.0 & 20.25 & 1.16 & 18.0 & 22.0 & 981 & 46 & 900 & 1050 & 30.5 \\
\hline & T34 & 44 & 11.98 & 1.42 & 7.5 & 14.5 & 3.82 & 2.16 & -1.0 & 7.5 & 19.76 & 1.50 & 15.5 & 22.5 & 880 & 148 & 600 & 1100 & 29.0 \\
\hline & T35 & 8 & 12.56 & 1.18 & 10.5 & 14.5 & 3.75 & 1.87 & 0.5 & 6.0 & 20.25 & 1.16 & 18.0 & 22.0 & 981 & 46 & 900 & 1050 & 30.5 \\
\hline & T36 & 8 & 12.56 & 1.18 & 10.5 & 14.5 & 3.75 & 1.87 & 0.5 & 6.0 & 20.25 & 1.16 & 18.0 & 22.0 & 981 & 46 & 900 & 1050 & 30.5 \\
\hline & T37 & 8 & 12.56 & 1.18 & 10.5 & 14.5 & 3.75 & 1.87 & 0.5 & 6.0 & 20.25 & 1.16 & 18.0 & 22.0 & 981 & 46 & 900 & 1050 & 30.5 \\
\hline & T38 & 63 & 11.45 & 1.94 & 6.0 & 14.0 & 3.49 & 1.95 & -1.0 & 7.5 & 19.59 & 1.67 & 15.0 & 22.5 & 975 & 206 & 550 & 1500 & 29.4 \\
\hline & $\mathrm{T} 40$ & 8 & 12.56 & 1.18 & 10.5 & 14.5 & 3.75 & 1.87 & 0.5 & 6.0 & 20.25 & 1.16 & 18.0 & 22.0 & 981 & 46 & 900 & 1050 & 30.5 \\
\hline & $\mathrm{T} 41$ & 8 & 12.56 & 1.18 & 10.5 & 14.5 & 3.75 & 1.87 & 0.5 & 6.0 & 20.25 & 1.16 & 18.0 & 22.0 & 981 & 46 & 900 & 1050 & 30.5 \\
\hline & $\mathrm{T} 42$ & no & & & & & no data & & & & no data & & & & no data & & & & \\
\hline & $\mathrm{T} 43$ & 8 & 12.56 & 1.18 & 10.5 & 14.5 & 3.75 & 1.87 & 0.5 & 6.0 & 20.25 & 1.16 & 18.0 & 22.0 & 981 & 46 & 900 & 1050 & 30.5 \\
\hline & $\mathrm{T} 44$ & 8 & 12.56 & 1.18 & 10.5 & 14.5 & 3.75 & 1.87 & 0.5 & 6.0 & 20.25 & 1.16 & 18.0 & 22.0 & 981 & 46 & 900 & 1050 & 30.5 \\
\hline & $\mathrm{T} 45$ & 8 & 12.56 & 1.18 & 10.5 & 14.5 & 3.75 & 1.87 & 0.5 & 6.0 & 20.25 & 1.16 & 18.0 & 22.0 & 981 & 46 & 900 & 1050 & 30.5 \\
\hline & $\mathrm{T} 47$ & 8 & 12.38 & 1.30 & 10.0 & 14.0 & 3.25 & 2.17 & 0.0 & 6.0 & 20.13 & 1.16 & 18.0 & 22.0 & 1025 & 46 & 950 & 1100 & 31.5 \\
\hline & T48 & 8 & 12.56 & 1.18 & 10.5 & 14.5 & 3.75 & 1.87 & 0.5 & 6.0 & 20.25 & 1.16 & 18.0 & 22.0 & 981 & 46 & 900 & 1050 & 30.5 \\
\hline & $\mathrm{T} 49$ & 22 & 11.18 & 1.92 & 6.0 & 14.5 & 2.98 & 1.89 & -0.5 & 6.0 & 19.32 & 1.51 & 16.5 & 22.0 & 955 & 116 & 650 & 1200 & 30.1 \\
\hline & T50 & 8 & 12.56 & 1.18 & 10.5 & 14.5 & 3.75 & 1.87 & 0.5 & 6.0 & 20.25 & 1.16 & 18.0 & 22.0 & 981 & 46 & 900 & 1050 & 30.5 \\
\hline & T51 & 18 & 11.47 & 1.59 & 7.0 & 14.0 & 3.72 & 1.65 & 0.5 & 6.0 & 19.56 & 1.28 & 17.0 & 22.0 & 983 & 162 & 600 & 1200 & 28.7 \\
\hline & T52 & 27 & 10.74 & 2.31 & 5.5 & 14.0 & 2.76 & 2.31 & -1.0 & 6.5 & 18.98 & 1.79 & 15.5 & 22.0 & 943 & 137 & 600 & 1100 & 29.8 \\
\hline & T53 & 22 & 11.05 & 2.14 & 6.0 & 14.0 & 2.91 & 2.16 & -1.0 & 6.5 & 19.30 & 1.64 & 16.0 & 22.0 & 961 & 102 & 650 & 1100 & 30.2 \\
\hline & T54 & 22 & 11.05 & 2.14 & 6.0 & 14.0 & 2.91 & 2.16 & -1.0 & 6.5 & 19.30 & 1.64 & 16.0 & 22.0 & 961 & 102 & 650 & 1100 & 30.2 \\
\hline & T55 & 40 & 10.74 & 2.14 & 5.0 & 14.0 & 3.19 & 2.01 & -1.0 & 6.0 & 18.88 & 1.58 & 16.0 & 22.0 & 1049 & 193 & 650 & 1500 & 28.3 \\
\hline TD5 & T56 & no & & & & & no data & & & & no data & & & & no data & & & & \\
\hline & T57 & no & & & & & no data & & & & no data & & & & no data & & & & \\
\hline & T58 & 50 & 11.60 & 1.83 & 5.5 & 14.0 & 3.70 & 2.00 & -0.5 & 7.5 & 19.90 & 1.44 & 16.0 & 22.0 & 876 & 153 & 600 & 1200 & 29.7 \\
\hline & T59 & 50 & 11.60 & 1.83 & 5.5 & 14.0 & 3.70 & 2.00 & -0.5 & 7.5 & 19.90 & 1.44 & 16.0 & 22.0 & 876 & 153 & 600 & 1200 & 29.7 \\
\hline & T60 & 22 & 11.18 & 1.92 & 6.0 & 14.5 & 2.98 & 1.89 & -0.5 & 6.0 & 19.32 & 1.51 & 16.5 & 22.0 & 955 & 116 & 650 & 1200 & 30.1 \\
\hline & T61 & 22 & 11.18 & 1.92 & 6.0 & 14.5 & 2.98 & 1.89 & -0.5 & 6.0 & 19.32 & 1.51 & 16.5 & 22.0 & 955 & 116 & 650 & 1200 & 30.1 \\
\hline & T62 & 80 & 11.26 & 2.02 & 5.5 & 14.5 & 3.53 & 1.97 & -1.0 & 7.5 & 19.42 & 1.51 & 16.0 & 22.5 & 984 & 207 & 600 & 1500 & 28.9 \\
\hline & T63 & 22 & 11.18 & 1.92 & 6.0 & 14.5 & 2.98 & 1.89 & -0.5 & 6.0 & 19.32 & 1.51 & 16.5 & 22.0 & 955 & 116 & 650 & 1200 & 30.1 \\
\hline & T64 & 22 & 11.18 & 1.92 & 6.0 & 14.5 & 2.98 & 1.89 & -0.5 & 6.0 & 19.32 & 1.51 & 16.5 & 22.0 & 955 & 116 & 650 & 1200 & 30.1 \\
\hline & T65 & 11 & 12.18 & 0.96 & 11.0 & 14.0 & 3.32 & 1.75 & 1.0 & 5.5 & 19.95 & 0.93 & 18.5 & 22.0 & 977 & 117 & 650 & 1100 & 30.9 \\
\hline & T66 & 13 & 11.77 & 1.49 & 8.0 & 14.0 & 3.31 & 1.89 & 0.5 & 6.0 & 20.00 & 1.02 & 18.5 & 22.0 & 981 & 101 & 700 & 1100 & 31.0 \\
\hline & T67 & 19 & 11.58 & 1.46 & 8.5 & 14.0 & 3.13 & 2.10 & -0.5 & 6.0 & 18.50 & 2.05 & 16.0 & 22.0 & 976 & 103 & 650 & 1100 & 27.5 \\
\hline & T68 & 11 & 12.18 & 0.96 & 11.0 & 14.0 & 3.32 & 1.75 & 1.0 & 5.5 & 19.95 & 0.93 & 18.5 & 22.0 & 977 & 117 & 650 & 1100 & 30.9 \\
\hline & T69 & 50 & 11.60 & 1.83 & 5.5 & 14.0 & 3.70 & 2.00 & -0.5 & 7.5 & 19.90 & 1.44 & 16.0 & 22.0 & 876 & 153 & 600 & 1200 & 29.7 \\
\hline & T70 & 19 & 11.58 & 1.46 & 8.5 & 14.0 & 3.13 & 2.10 & -0.5 & 6.0 & 18.50 & 2.05 & 16.0 & 22.0 & 976 & 103 & 650 & 1100 & 27.5 \\
\hline & T71 & 13 & 11.77 & 1.49 & 8.0 & 14.0 & 3.31 & 1.89 & 0.5 & 6.0 & 20.00 & 1.02 & 18.5 & 22.0 & 981 & 101 & 700 & 1100 & 31.0 \\
\hline & $\mathrm{T} 72$ & 88 & 9.96 & 2.25 & 5.5 & 14.5 & 2.56 & 1.84 & -1.0 & 7.0 & 18.56 & 1.76 & 16.0 & 22.0 & 928 & 220 & 500 & 1500 & 29.2 \\
\hline & $\mathrm{T} 73$ & no & & & & & no data & & & & no data & & & & no data & & & & \\
\hline & $\mathrm{T} 74$ & 13 & 12.15 & 1.25 & 10.5 & 14.5 & 3.31 & 1.96 & 0.5 & 6.0 & 20.00 & 1.02 & 18.5 & 22.0 & 938 & 160 & 600 & 1100 & 31.0 \\
\hline & T75 & no & & & & & no data & & & & no data & & & & no data & & & & \\
\hline & T76 & no & & & & & no data & & & & no data & & & & no data & & & & \\
\hline
\end{tabular}




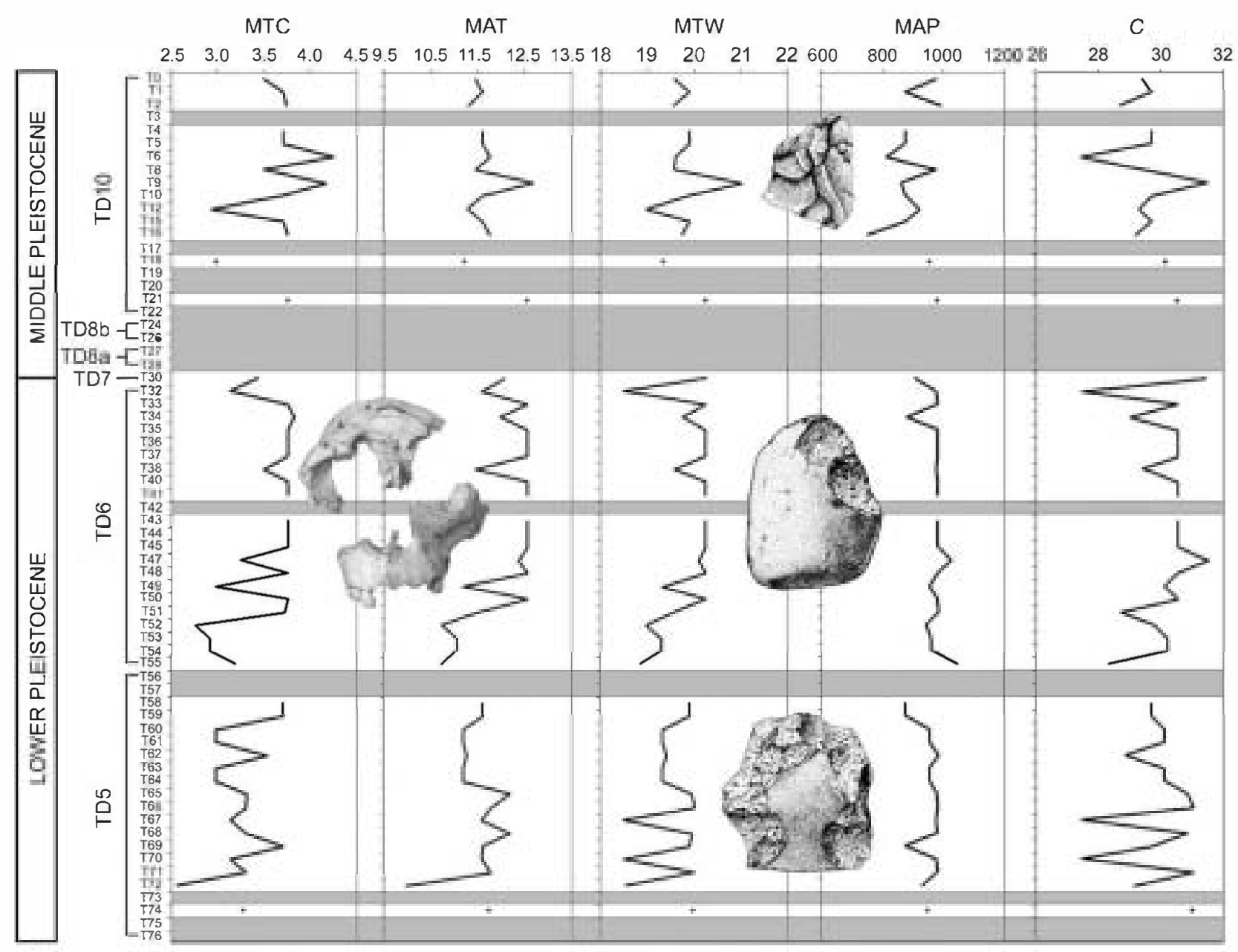

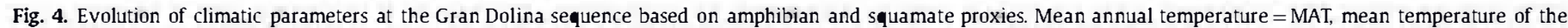

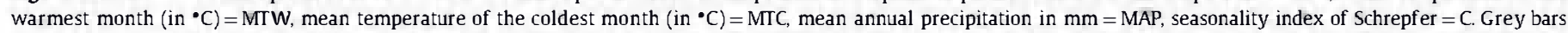

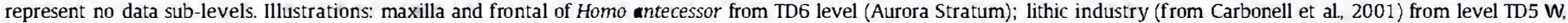
TD6 (Mode 1), and TD10 (early Mode 3).

including: large porcupine Hystrix refossa, Canis mosbachensis, Mustela palerminea, and Lynx sp. (Cuenca-Bescós et al., 1999; Cuenca-Bescós and García, 2007).

TD7

In level TD7, the amphibian and squamate proxies indicate a rather open-humid environment (Blain et al., 2008a). As other disciplines reveal, the climate seems to be neither particularly warm nor cold.

\section{TD8a and TD8b}

In TD8a, the MCR method does not yield any results, because the distributions of the taxa do not overlap. Nevertheless, as suggested in Blain et al. (2008a), amphibian and squamate proportions in TD8a, and in particular the presence of Blanus cinereus, Pelobates cultripes, and Rhinechis scalaris, indicate warm and dry conditions. Such warm conditions are supported by the presence of the large porcupine and Hippopotamus in this level (Cuenca-Bescós and Garcia, 2007). The two pollen samples from TD8 include a significant numbers of Castanea together with the usual Gran Dolina taxa, which together indicate warm, temperate, and humid conditions (García Antón, 1995). The very small number of amphibian and squamate remains in TD8b does not permit any palaeoclimatic reconstruction.

TD10

Like the small mammals (Cuenca-Bescós et al., 2005) and palynology (García Antón, 1995), amphibian and squamate proxies suggest that only the bottom of TD10 (sub-levels T20-22) may be warm-temperate (with the presence of Coronella girondica and Vipera latasti), and that from sub-level T19 upwards there is a steplike transition to cooler conditions. The pollen (which comes from the lower part of TD10) shows an increase in Pinus (reaching 50\% of the total pollen count), accompanied by a reduction in Mediterranean components (Olea) and temperate species (deciduous Quercus). This is considered by García Antón (1995) to represent a transition to a cold phase.

In conclusion, amphibians and squamate reptiles permit a re-examination of the data from other palaeoclimatic proxies and tend to smooth their strong interpretation in term of cold-warm alternations throughout the Gran Dolina sequence. Throughout the studied sequence, our data suggest a climate that varies mainly following interpretations from the other proxies, but is always warmer than current temperatures in the Burgos area. Differences observed in calculated mean temperature are approximately about $2{ }^{\circ} \mathrm{C}$ between "cold" and "warm" periods. However, these 


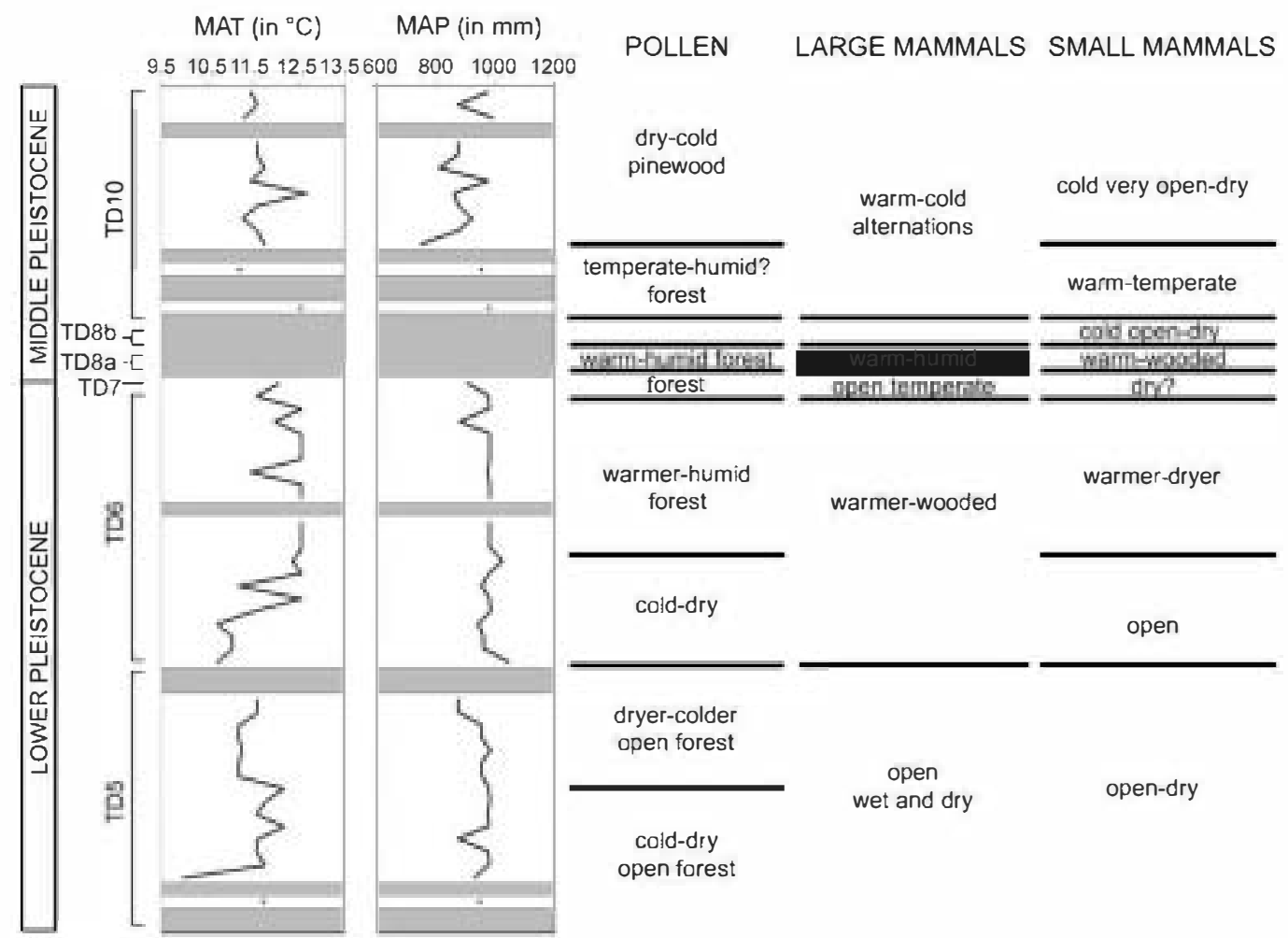

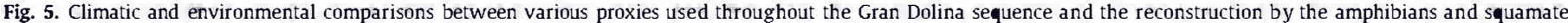
reptiles. Pollen after García Antôn (1989), large mammals after van der Made (1998) and García and Arsuaga (1999), small mammals after Cuenca-Bescós et al. (2005).

seemingly small variations observed in the Sierra de Atapuerca correspond to important reorganization of the vegetation and fauna on a continental scale, as illustrated by the amphibians and squamate reptiles.

\section{Conclusion}

The overlap of the current distribution areas of all amphibian and squamate reptile taxa occurring in Gran Dolina sub-levels permits us to estimate potential palaeoclimatic conditions. This method estimates MAT levels ranging between 10 and $13^{\circ} \mathrm{C}$ (i.e., warmer than present day Burgos for all of the studied sequence). Rainfall is also higher. This study corroborates alternations of temperatures within a warm-temperate period during the early Pleistocene which is concordant with quantitative variation in the herpetofauna throughout the sequence.

Thus, the implications for hominin palaeoecology seem clear: on the important issue of first hominin dispersal into Western Europe, data from level TD5 and TD6 show that Homo antecessor was present in the Iberian Peninsula during a warm and rather humid period, favourable to hominin survival with the presence of a diverse megafauna as evidenced by large mammal remains found in the Gran Dolina. Until now there is no evidence that Homo antecessor was able to produce fire, and by consequence temperatures may have been an essential component of their ability to colonize new environments.

As far as Homo heidelbergensis is concerned, the various occupations of level TD10 occur in a rather temperate-warm period. This species may have produced fire, as evidenced by a few hearths (Terra Amata and Menez Dregan in France and Vertessöllos in Hungary, all at approximately $0.45 \mathrm{Ma}$ ) and so $\mathrm{H}$. heidelbergensis is likely to be more independent of the climatic conditions than $H$. antecessor.

Many publications have suggested that the Sierra de Atapuerca was an idyllic place for the success of fossil hominins, because of its situation in the Burreba corridor at the confluence between the Ebro and Duero rivers basin (migration routes of large mammals), with the proximity of the Arlanzon river, and nearby sources of flint and quartzite for making tools. In addition, herpetofaunal assemblages show that temperate-warm climatic conditions were favourable for the sustainability of the various human settlements in the Sierra de Atapuerca, during the latest early Pleistocene and late middle Pleistocene.

\section{Acknowledgments}

The authors are deeply indebted to A. Olle (IPHES-URV, Tarragona) and B. Martínez-Navarro (ICREA-IPHES, Tarragona) who critically reviewed an earlier draft. R. Huguet and J. Rosell (IPHESURV, Tarragona), as well as Dr. Susan Antón and anonymous reviewers strongly improved this manuscript by their comments. The Atapuerca excavation team helped with the extraction, sieving, and washing of sediments each year. The sorting of material was supported by the Junta de Castilla y León, the Ministerio de Educacion y Ciencia project CGI.2006-13532-C03-02, the INAEM contracts, and the University of Zaragoza.

\section{Ref erences}

Andrews, P, 1990. Owls, Caves and Fossils. Natural History Museum, London. Barbadillo, LJ., García-París, M., Sanchiz, B., 1997. Orígenes y relaciones evolutivas de la herpetofauna ibérica. In: Pleguezuelos, J.M., Martinez-Rica, J.P. (Eds.), Distribución y Biogeografia de los anfibios y reptiles de España: Monografias Revista Española de Herpetología 3. Universidad de Granada, Granada, pp. 47-100.

Berger, G.W., Pérez-González, A., Carbonell, E., Arsuaga, J.L., Bermúdez de Castro,J.-M., $\mathrm{Ku}, \mathrm{T}$.-L, 2008. Luminescence chronology of cave sediments at the Atapuerca paleoanthropological site, Spain. J. Hum. Evol. 55, 300-311.

Bermúdez de Castro, J.M., Arsuaga, J.L., Carbonell, E., Rosas, A., Martínez, I., Mosquera, M., 1997. A hominid from the Lower Pleistocene of Atapuerca, Spain: possible ancestor to Neanderthals and modern humans. Science 276, 1392-1395. 
Bermúdez de Castro, J.M., Martinón-Torres, M., Carbonell, E., Sarmiento, S., Rosas, A. van der Made, J., Lozano, M., 2004. The Atapuerca sites and their contribution to the knowledge of human evolution in Europe. Evol. Anthropol. 13, 25-41.

Blain, H.-A., 2005. Conrribution de la Paléoherpétof aune (Amphibia \& Squamata) à la connaissance de l'évolution du climat et du paysage du Pliocène supérieur au Pléistocène moyen d'Espagne. Ph.D. Dissertation, Muséum national d'Histoire naturelle de Paris, Institut de Paléontologie Humaine.

Blain, H.-A., Bailon, S., Agustí, J., 2007. Anurans and squamate reptiles from the latest early Pleistocene of Almenara-Casablanca-3 (Castellón, East of Spain). Systematic, climatic and environmental considerations. Geodiversitas 29, 269-295.

Blain, H.-A., Bailon, S., Agusi, J., 2008b. Amphibians and squamate reptiles from the latest early Pleistocene of Cueva Victoria (Murcia, southeastern Spain, SW Mediterranean): paleobiogeographic and paleoclimatic implications. Geol. Acta 6, 345-361

Blain, H.-A., Bailon, S., Cuenca-Bescós, G., 2008a. The Early-Middle Pleistocene palaeoenvironmental change based on the squamate reptile and amphibian proxy at the Gran Dolina site, Atapuerca, Spain. Palaeogeogr. Palaeoclimatol. 261, 177-192.

Carbonell, E., Bermúdez de Castro, J.M., Arsuaga, J.L, Díez, J.C., Rosas, A., CuencaBescós, G. Sala, R., Mosquera, M., Rodríguez, X.P., 1995. Lower Pleistocene hominids and artifacts from Atapuerca-TD6 (Spain). Science 269, 826-832.

Carbonell, E., Mosquera, M., -llé, A., Rodriguez, X.P., Sahnouni, M., Sala, R. Vergès, J.M., 2001. Structure morphotechnique de l'industrie lithique du Pleistocène inférieur et moyen d'Atapuerca (Burgos, Espagne). L'Anthropologie 105 259-280.

Carbonell, E., Bermúdez de Castro, J.M., Parés, J.M., Pérez-González, A., CuencaBescós, G., llé, A., Mosquera, M., Huguet, R, van der Made, J., Rosas, A., Sala, R. Vallverdú, J., García, N., Granger, D.E., Martinón-Torres, M., Rodríguez, X.P. Stock, G.M., Vergès, J.M., Allué, E., Bur jachs, F., Cáceres, I., Canals, A., Benito, A. Díez, C., Lozano, M., Mateos, A., Navazo, M., Rodríguez, J., Rosell, J., Arsuaga, J.L. 2008. The first hominin of Europe. Nature 452, 465-469.

Cuenca-Bescós, G., Canudo, J.1., Laplana, C., 1995. Los arvicólidos (Rodentia, Mammalia) de los niveles inferiores de Gran Dolina (Pleistoceno Inferior, Atapuerca, Burgos, España). Revista Española de Paleontología 10, 202-218.

Cuenca-Bescós, G., García, N., 2007. Biostratigraphic succession of the Early and Middle Pleistocene mammal faunas of the Atapuerca cave sites (Burgos, Spain). Courier Forschungsinstitut Senckenberg 259, 99-110.

Cuenca-Bescós, G., Laplana, C., Canudo, J.1., 1999. Biochronological implications of the Arvicolidae (Rodentia, Mammalia) from the Lower Pleistocene hominidbearing level of Trinchera Dolina 6 (TD6, Atapuerca, Spain). J. Hum. Evol. 37 353-373.

Cuenca-Bescós, G., Rofes, J., García-Pimienta, J., 2005. Environmental change across the Early-Middle Pleistocene transition: small mammalian evidence from the Trinchera Dolina cave, Atapuerca, Spain. In: Head, M.J., Gibbard, P.L. (Eds.) Early-Middle Pleistocene Transitions: The Land-acean Evidence. Geol. Soc London Spec. Publ. 247, 277-286

Díez, J.C., Fernández-Jalvo, Y., Rosell, J, Cáceres, I., 1999. Zooarchaeology and taphonomy of Aurora Sratum (Gran Dolina, Sierra de Atapuerca, Spain). J. Hum. Evol. 37, 623-652.

Díez, J.C., Rosell, J., 1998. Estrategias de subsistencia de los hominidos en la Sierra de Atapuerca. In: Aguirre, E. (Ed.), Atapuerca y la Evolución Humana. Fundación Ramón Areces, Madrid, pp. 363-390.

Esteban, M., 1996. Zooarqueologia del nivell 10 de Trinchera Dolina, Sierra de Atapuerca, Burgos. M.D. Dissertation. Universitat Rovira I Virgili, Tarragona.
Falguères, C., Bahain, J.-J., Yokoyama, Y., Arsuaga, J.L., Bermúdez de Castro, J.M., Carbonell, E., Bischoff, J.L., Dolo, J.M., 1999. Earliest humans in Europe: the age of TD6 Gran Dolina, Atapuerca, Spain. J. Hum. Evol. 37, 343-352.

Fernández-Jalvo, Y., 1996. Small mammal taphonomy and the Middle Pleistocene environments of Dolina, northern Spain. Quatern. Int. 33, 21-34.

Fernández-Jalvo, Y., Andrews, P., 1992. Small mammal taphonomy of Gran Dolina, Atapuerca (Burgos), Spain. J. Archaeol. Sci. 19, 407-428.

Font Tullot, I., 1983. Atlas Climatico de España. Ministerio de Transportes, Turismo y Communicaciones, Instituto Nacional de Meteorologia, Madrid.

Font Tullot, I., 2000. Climatología de España y Portugal, second ed. Ediciones Universidad de Salamanca.

García, N., Arsuaga, J.L, 1999. Carnivores from the Early Pleistocene hominid-bearing Trinchera Dolina 6 (Sierra de Atapuerca, Spain). J. Hum. Evol. 37, 175-190.

García Antón, M., 1989. Estudio palinológico de los yacimientos mesopleistocenos de Atapuerca (Burgos): Reconstrucción paisajistica y paleoclimática. Universidad Autónoma de Madrid, Facultad de Ciencias, Departamento de Biología

García Antón, M., 1995. Paleovegetación del Pleistoceno Medio de Atapuerca a ravés del análisis polínico. In: Bermúdez de Castro, J.M., Arsuaga, J.L, Carbonell, E. (Eds.), Evolución Humana en Europa y los yacimientos de la Sierra de Atapuerca. Junta de Castilla y León, Valladolid, pp. 147-165.

García Antón, M., Sainz @lero, H., 1991. Pollen records from the middle Pleistocene Atapuerca site (Burgos, Spain). Palaeogeogr. Palaeoclimatol. 85, 199-206.

Huguet Pàmies, R, 2007. Primeras occupaciones humanas en la Península lbérica: Paleoeconomia de la Sierra de Atapuerca (Burgos) y la Cuenca de Guadix-Baza (Granada) durante el Pleistoceno Inf erior. Ph.D. Dissertation, Universitat Rovira i Virgili, Tarragona.

López Antoñanzas, R, Cuenca Bescós, G, 2002. The Gran Dolina site (Lower to Middle Pleistocene, Atapuerca, Burgos, Spain): new palaeoenvironmental data based on the distribution of small mammals. Palaeogeogr. Palaeoclimatol. 186, 311-334.

van der Made, J., 1998. Ungulates from Gran Dolina (Atapuerca, Burgos, Spain). Quaternaire 9, 267-281.

Parés, J.M., Pérez-González, A., 1999. Magnetochronology and stratigraphy at Gran Dolina section, Atapuerca (Burgos, Spain). J. Hum. Evol. 37, 325-342.

Pinto Llona, A.C., Andrews, P.J., 1999. Amphibian taphonomy and its application to the fossil record of Dolina (middle Pleistocene, Atapuerca, Spain). Palaeogeogr. Palaeoclimatol. 149, 411-429.

Pleguezuelos, J.M., Márquez, M., Lizana, M., 2004. Atlas y libro rojo de los Anfibios y Reptiles de España, third ed. Dirección General de Conservación de la Naturaleza-Asociación Herpetológica Española, Madrid.

Pross, J., Klotz, S., 2002. Palaeotemperature calculations from the Praetiglian/Tiglian (Plio-Pleistocene) pollen record of Lieth, northern Germany: implications for the climatic evolution of NW Europe. Global Planet. Change 34, 253-267.

Rage, J.-C., Roček, Z., 2002. Evolution of anuran assemblages in the Tertiary and Quaternary of Europe, in the context of palaeoclimate and palaeogeography. Amphib.-Reptilia 24, 133-167.

Rivas-Marínez, S., 1986. Mapa E. 1: 400,000 de las series de vegetación de España, $n \bullet 8$ (Burgos). ICONIA, Madrid

Rosell, J., Caceres, I., Huguet, R, 1998. Systèmes d'occupation anthropique pendant le Pléistocène inférieur et moyen à la Sierra de Atapuerca (Burgos, Espagne). Quaternaire 9, 355-360.

Schrepfer, H., 1925. Die Kontinentalität des deutschen Klimas. Petermanns Geographische Mitteilungen 71, 49-51. 